\title{
Pressure monitoring in powered support legs in selected longwalls at Jastrzębska Spółka Węglowa S.A.
}

\begin{abstract}
This article presents the role of systems for monitoring the capacity of sections of the powered support forming part of mining complexes. It shows systems for monitoring powered support sections during the mining of coal deposits and the method of transmitting measurements of pressure in hydraulic legs to the analytical system used at Jastrzębska Spótka Węglowa S.A. The results of an evaluation of the interaction between the powered support and the rock mass and the manner of their presentation are provided.
\end{abstract}

Key words: mining, powered support, capacity

\section{INTRODUCTION}

Jastrzębska Spółka Węglowa S.A. (JWS S.A.) comprises five hard coal mines in which coal seams are exploited with the use of modern mining complexes. Powered support is one of the primary components of the said mining complexes, determining the safety of employees and the stability of the longwall working and thereby ensuring an appropriate mining level [1]. The principle of operation of powered support provides for a controlled reduction of the support when it is loaded from the side of the roof by a force arising from the capacity at yield of the support itself. Capacity at yield is a parameter that defines the boundary capacity of the powered support to carry pressures coming from a roof opened by mining operations. It is measured as the pressure of roof rocks on a single support section, which generates such pressure in the hydraulic legs that is equal to the setpoint on the valve blocks protecting the said legs $[2,3]$. It is obvious, thus, that it is the control of the said pressure that is extremely significant in the coal seam mining process. These systems help advance the sections and permit the visualization of parameters such as: pressure in section's hydraulic legs, time of measurement performance, time of running of process engineering operations, moments of occurrence of irregularities or failures. At present, monitoring systems at JSW operate on several longwalls and, ultimately, they are supposed to be used on all of them. It must be noted that such systems are expensive and, for this reason, powered supports operating in the harshest geological conditions are the first to be equipped with them [4].

\section{DATA ANALYSIS}

JSW S.A. has been operating a Sophisticated Data Research Center for several years. It is tasked, among others, with analyzing process engineering data based on an integrated IT system for managing data coming from production processes, which comprises a Central Process Engineering Data Server (CSDT). The system is based on a platform that enables real-time processing of large information sets and easy integration with business systems, at the same time providing ICT security of physical systems. Data from all longwall shearers which are covered by systems for powered support section monitoring are transmitted to CSDT and processed for the purpose of gaining a broad evaluation of the interaction between the powered support and the rock mass. Such information is determined based on the pressure present in the legs of the powered support section. The obtained results are presented and reported to the relevant mine service staff.

\section{MINING OF DEPOSITS}

The mining of underground coal deposits by means of a longwall system employs a mining complex comprising among others powered support, the primary task of which is to ensure the longwall working stability and crew safety. One of the key actions to improve work safety and allow an increase in the production effectiveness is the evaluation of operation of the relevant powered support. When analyzing the interaction between 
the powered support and the rock mass, certain aspects exerting significant influence on the longwall working stability can be determined. A loss of working stability results in a roof fall or caving in the longwall, which may be related to the following irregularities in the operation of powered supports $[5,6]$ : incorrect selection of sections for specified geological and mining conditions, failures of (damage to) individual components of sections, incorrect handling (use) of sections and incorrect

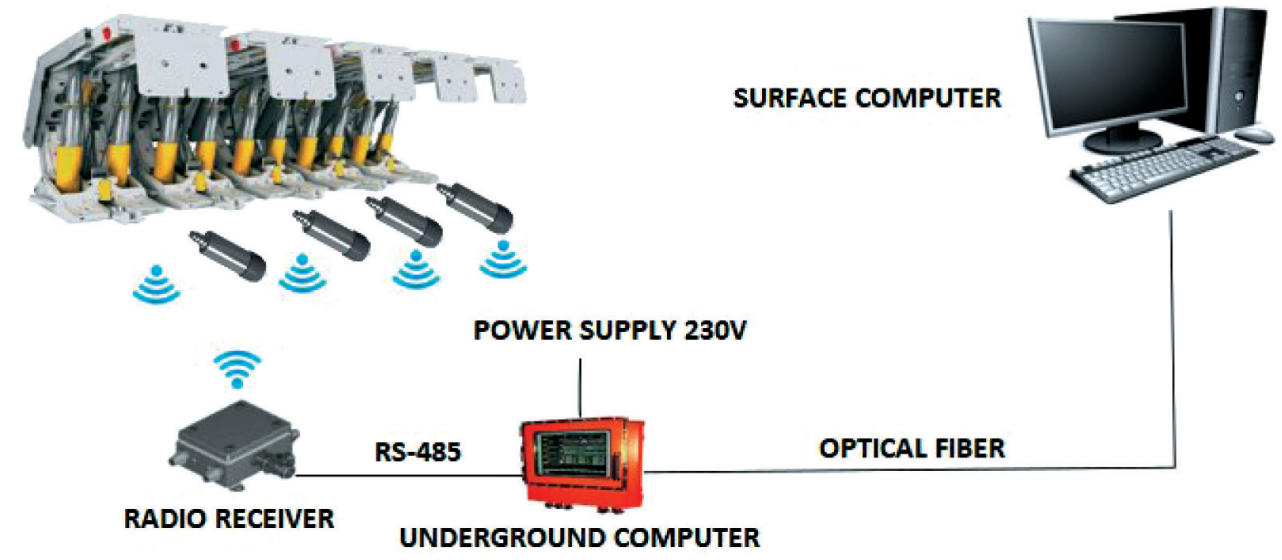

Fig. 1. Powered support capacity monitoring system geometrical form of the section structure. Owing to the monitoring of the section's operating cycle $[7,8]$, information may be obtained that refers, among others, to both the damage in the capacity part of the section's hydraulic system or the incorrect capacity at set value [9] and to the rock overhangs behind powered support sections that cause a considerable increase in the section load by the rock mass [10-12]. A view of a section with a data transmission system is presented in Figure 1.

\section{MEASUREMENT SYSTEMS}

For the purpose of ensuring the correct conditions of roof maintenance and the operation of powered support sections, they are equipped with appropriate measurement and signaling systems. At present, pressures in the parts under the pistons of the primary legs of powered support sections are measured and recorded, and then this information from the monitored longwalls in JWS's mines is sent to the Sophisticated Data Research Center.

Measurement systems allow local monitoring of support's operation with the use of computers adapted for use in underground conditions as well as on the mine's surface. Figures 2 and 3 present a view of the powered support section monitoring with the use of systems created by Centrum Hydrauliki DOH sp. z o.o. and the FAMUR Group.

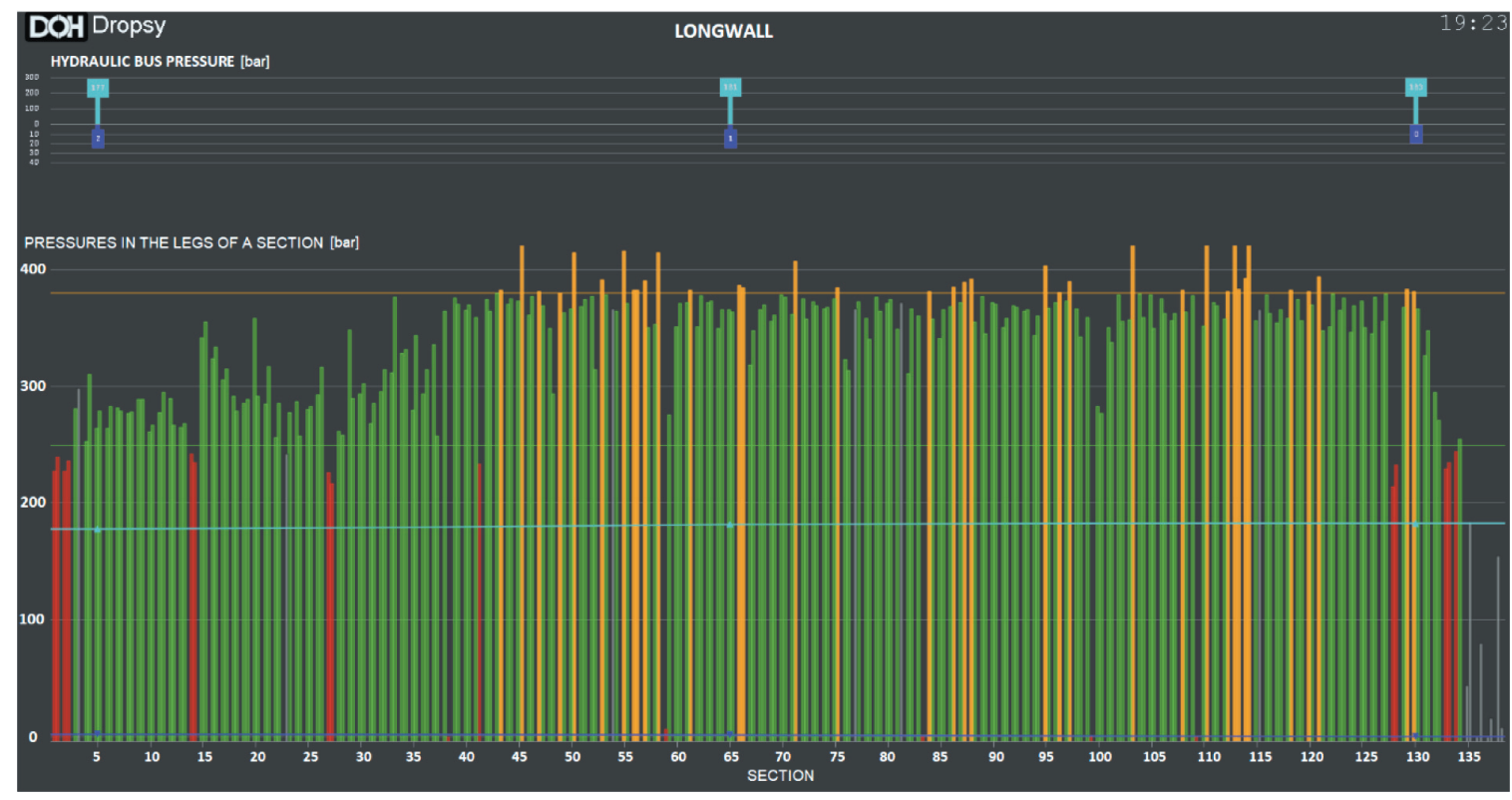

Fig. 2. Distribution of pressures in powered support legs - system created by Centrum Hydrauliki DOH sp. z o.o. 


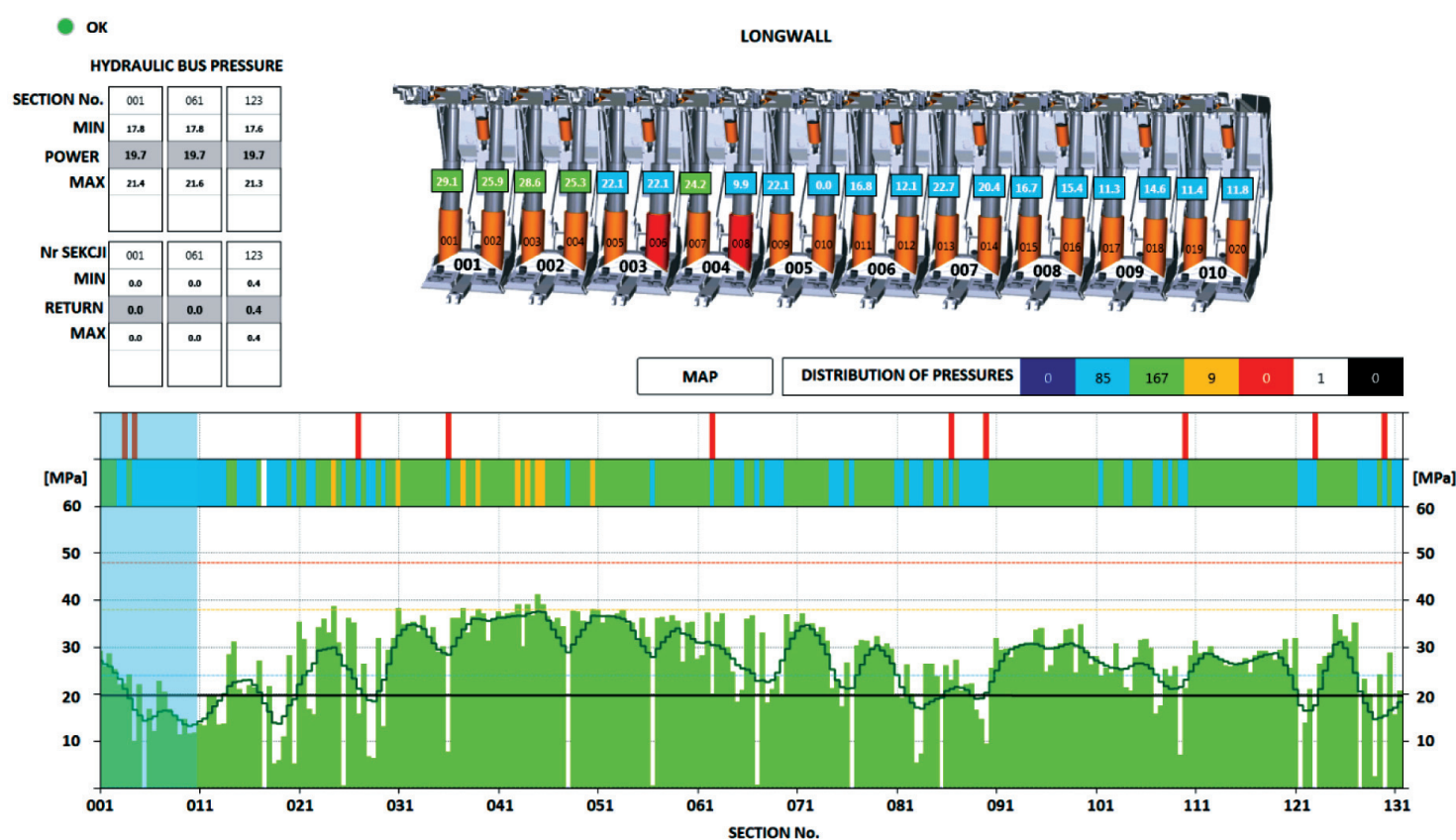

Fig. 3. Distribution of pressures in powered support legs - system created by the Famur Group

\section{ANALYSES AND ALERTS}

As a result of the analyses of pressure in the spaces under leg pistons, a range of events are identified in real time which require an appropriate reaction. Figure 4 reveals an asymmetry of pressures between the legs of a section, which indicates a leak in the leg's hydraulic system. This is visible after comparing with the correct powered support cycle in Figure 5. Figure 6 presents the tripping of a relief valve, which should trip on a specified pressure setpoint. It does not allow an increase in pressure above the permissible value specified by the section manufacturer. The following significant parameters are also identifiable based on pressure values: section withdrawal and expansion, and pressure in the main supply line [4].

It is important that the results of the analyses are delivered in real time and received directly by persons re- sponsible for the proper operation of the mining complex - the mine's maintenance service staff. This is not simply due to the large production scale at JSW. This task was accomplished with the use of tools by OSISoft - PI System [13]. The basic information from a longwall shearer and from a single section is presented in Figures 7 and 8, respectively. The person who uses such information should very quickly evaluate the operation of the powered support section as regards its interaction with the rock mass. A summary of all alerts and important events occurring during the operation of powered support, i.e. an event map, is presented in Figure 9. It shows such events occurring on individual powered support legs for the last 24 hours as: operating cycles, asymmetry of support, repeated tripping of the relief valve, incorrect value of capacity at set.

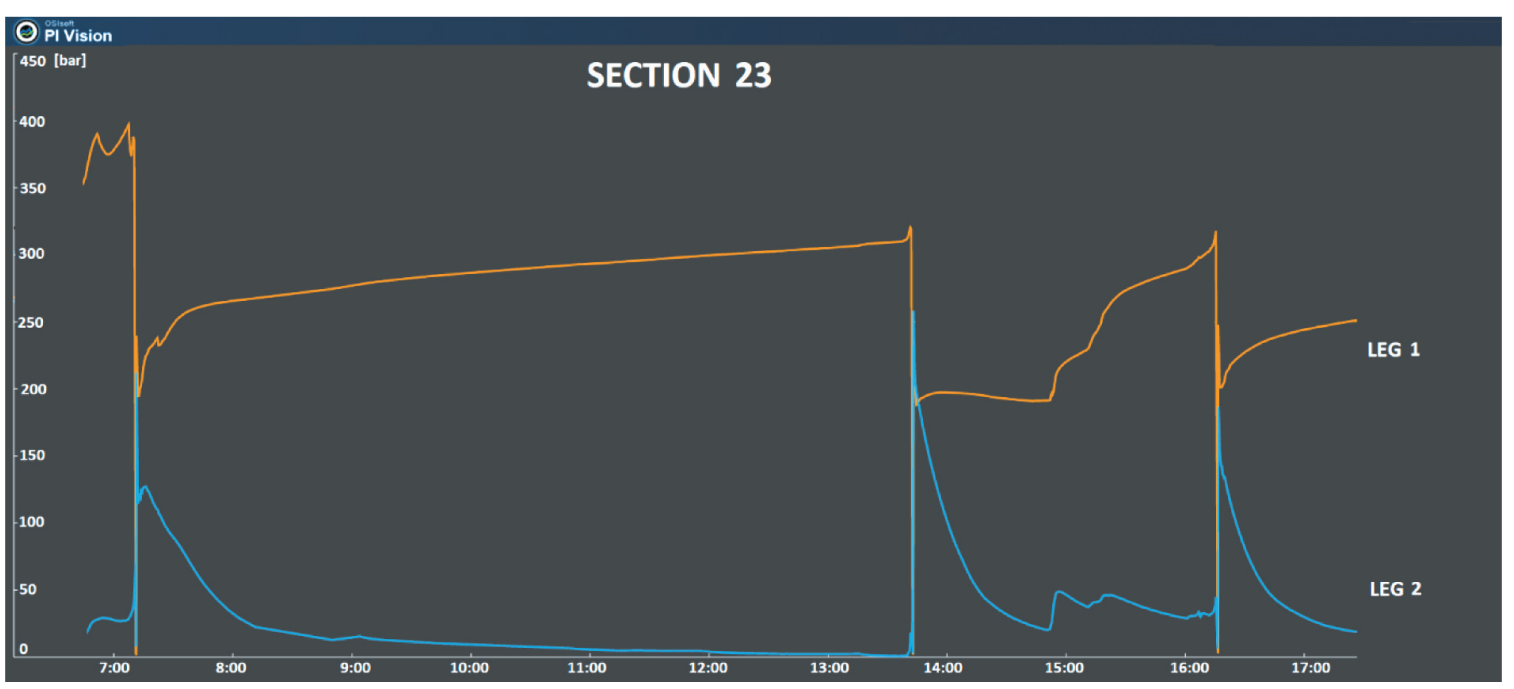

Fig. 4. Pressure asymmetry between section's legs 


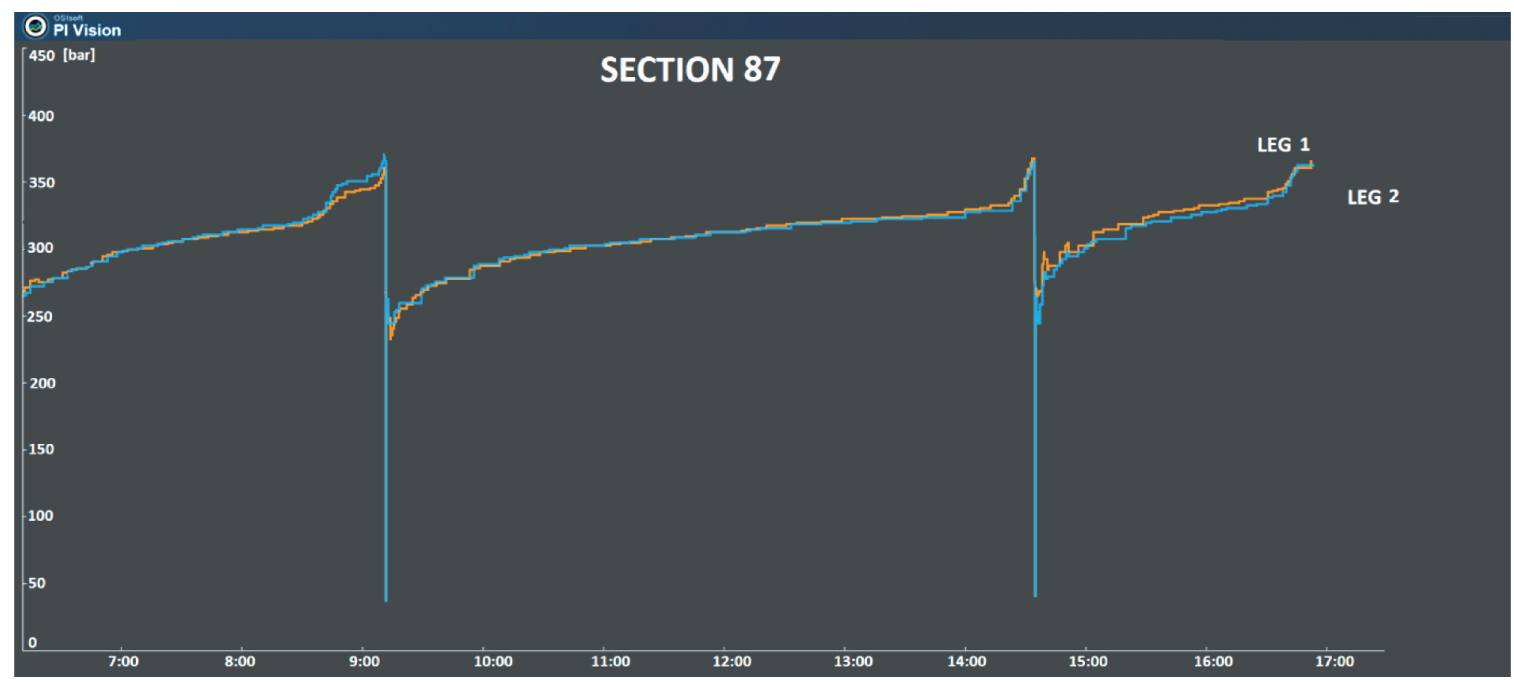

Fig. 5. Pressure measurement during successive operating cycles of the section

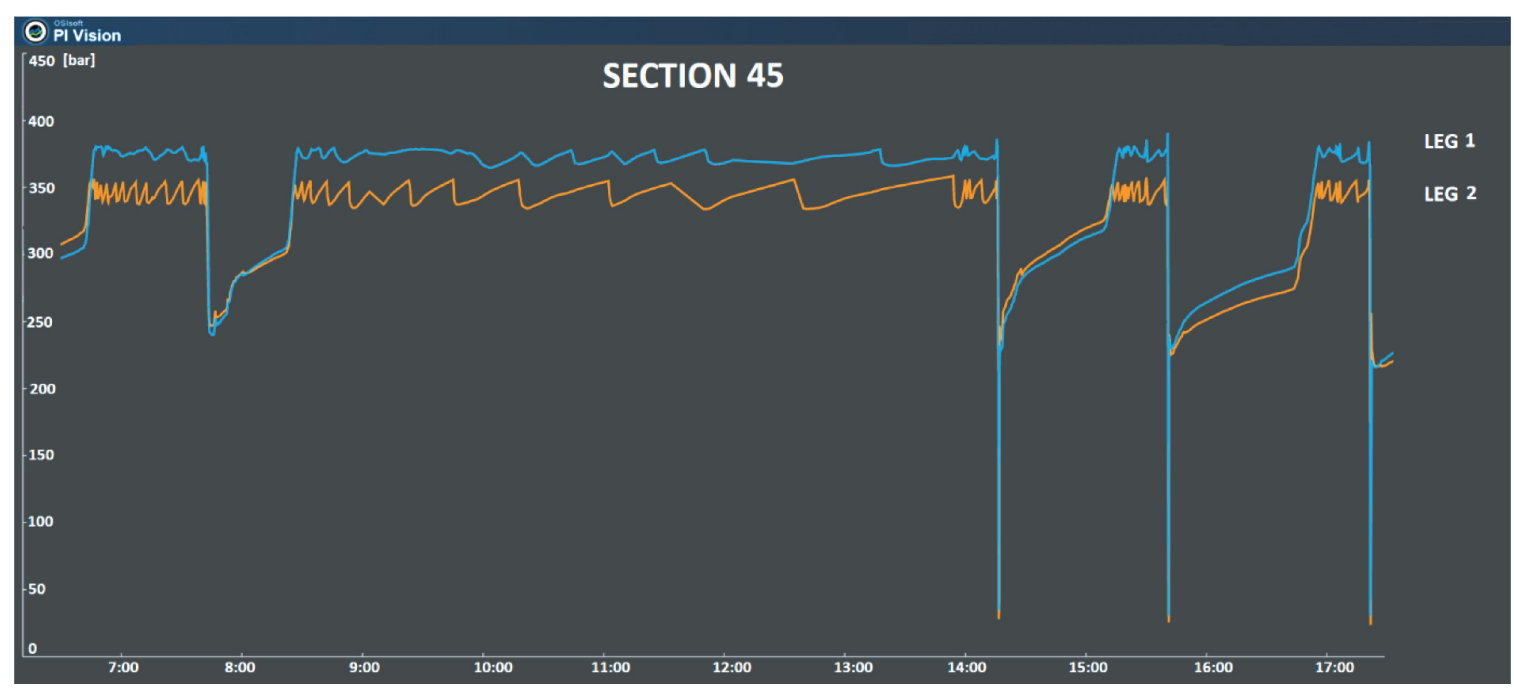

Fig. 6. Tripping of relief valve in section's leg

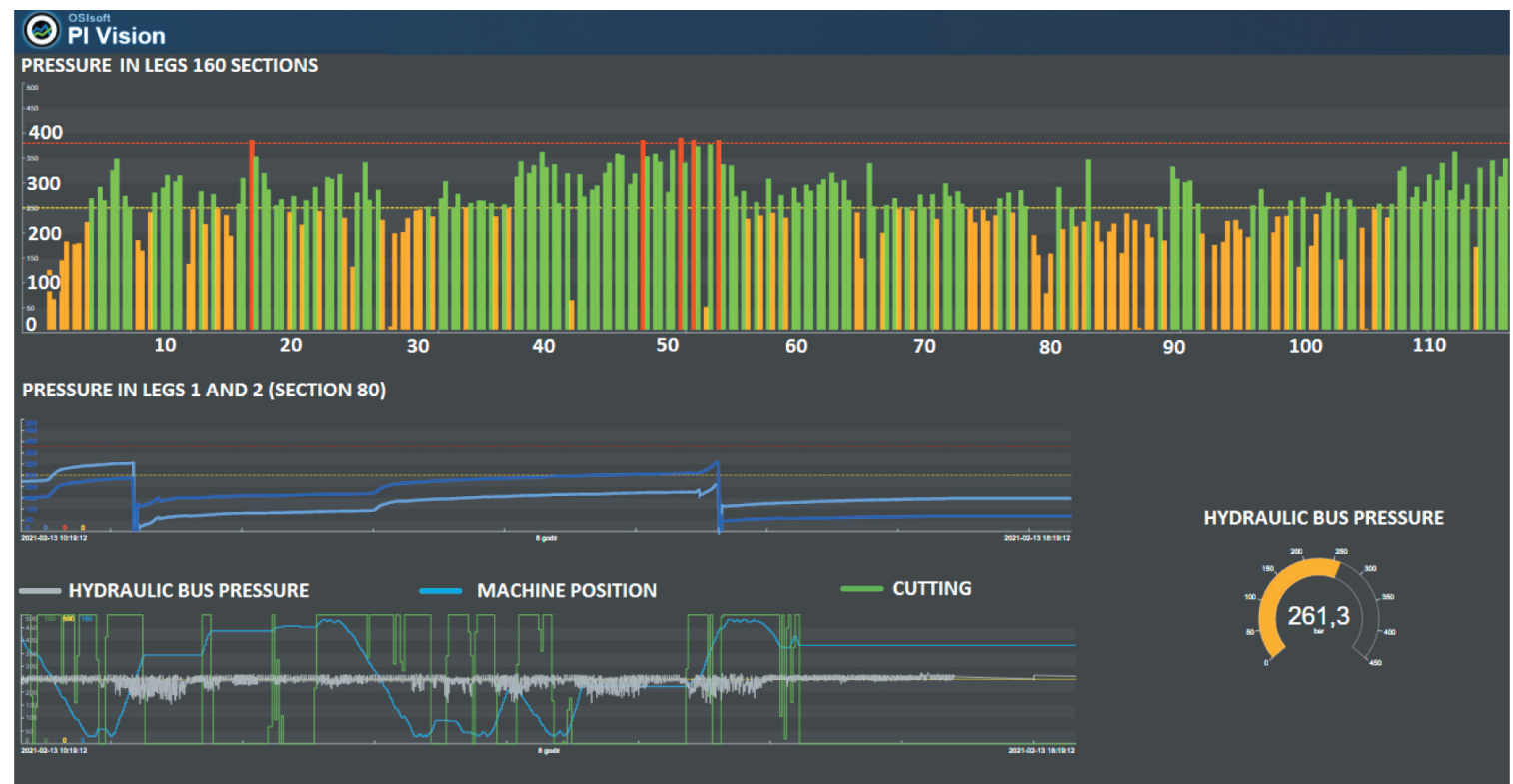

Fig. 7. Current view of pressures in powered support sections 


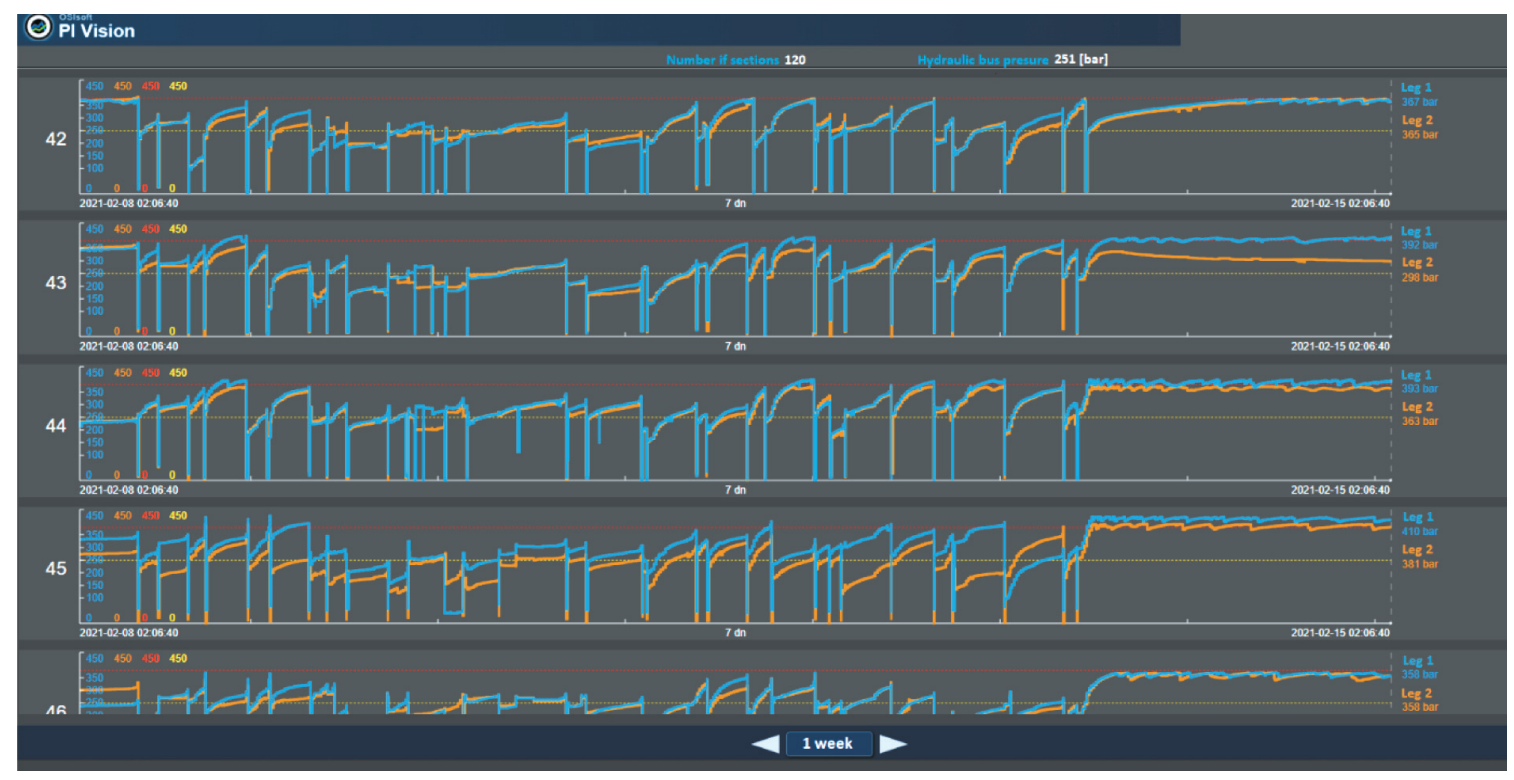

Fig. 8. View of pressures in selected sections

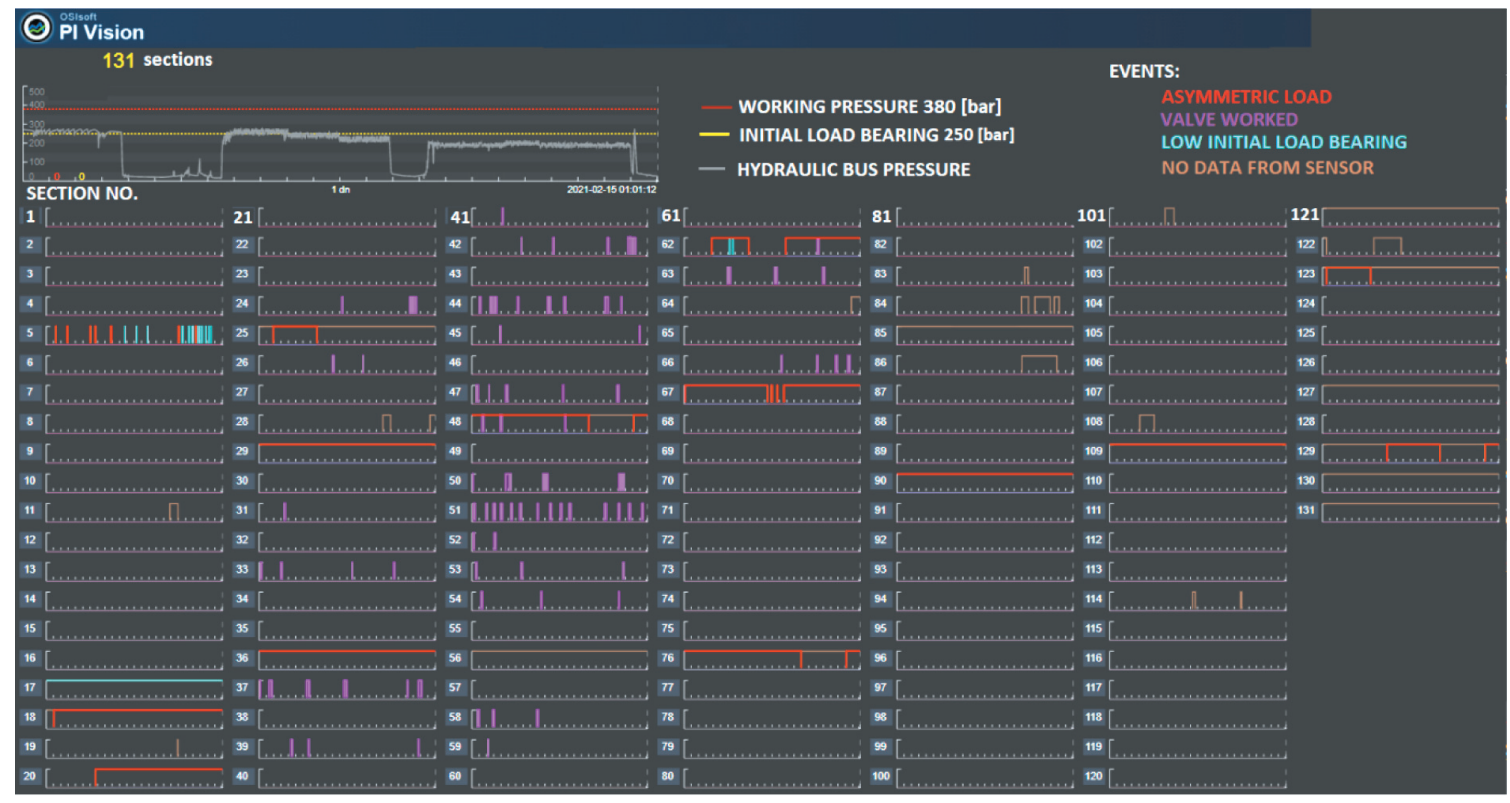

Fig. 9. Signaling of event occurrence in powered support sections

\section{CONCLUSION}

The implemented systems for the monitoring and analysis of section capacity enable a broad evaluation of the operation of powered support in the context of interaction with the rock mass. Due to the variety of factors affecting the support advancement, the interaction was evaluated by analyzing geological and organizational factors. The continuous control of capacity permits an evaluation of rock mass stress and a quicker reaction on the part of employees to achieve the correct state of rock mass equilibrium which has been disturbed during coal extraction. Such actions permit more effective remedial actions to be taken towards the impact of rock mass loosening (roof falls) during the course of mining. Work organization is a significant factor during support advancement. Owing to the monitoring of the section's operating cycle, information is obtained concerning, among others, the damage in the capacity part of the section's hydraulic system or the incorrect capacity at set value, or an overly long delay in supporting the newly uncovered roof, and the work culture of the longwall crew is improved.

The benefits achieved in this manner considerably improve crew safety and production effectiveness and extend the life of powered support. 


\section{References}

[1] Rajwa S., Prusek S., Walentek A., Płonka M.: Wpływ wybranych czynników na wspótpracę obudowy zmechanizowanej z górotworem $i$ warunki prowadzenia ściany, "Wiadomości Górnicze" 2015, 66, 10: 533-543.

[2] Obudowa zmechanizowana Hydrotech-JZR-14/39-PO Instrukcja obstugi i konserwacji Nr:01/2019/IOK, Jastrzębskie Zakłady Remontowe Spółka z o.o. [unpublished].

[3] Kulakiewicz A., Marianowski J.: Nowe rozwiąanie zabezpieczeń funkcjonowania upodatnionej obudowy zmechanizowanej, "Napędy i Sterowanie" 2011, 13, 7/8: 152-155.

[4] Płonka M.: Obraz podporności sekcji obudowy zmechanizowanej usytuowanej na pozycjach skrajnych na podstawie danych $z$ systemów monitoringu, "Przegląd Górniczy" 2018, 74, 3: 34-40.

[5] Rajwa S.: Główne przyczyny utraty stateczności wyrobiska ścianowego, "Bezpieczeństwo Pracy i Ochrona Środowiska w Górnictwie" 2017, 3: 3-12.

[6] Rajwa S.: Rozdziat 4. Stateczność wyrobiska ścianowego, [w:] K. Stoiński (red.), Zmechanizowane obudowy ścianowe dla warunków zagrożenia wstrząsami górotworu, Główny Instytut Górnictwa, Katowice 2018: 73-88.

[7] Peng S.S.: Longwall mining, $2^{\text {nd }}$ ed., Department of Mining Engineering, West Virginia University, Morgantown 2006.

[8] Cheng J., Wan Z., Peng S.S., Liu S., Ji Y.: What can the changes in shield resistance tell us during the period of shearer's cutting and neighboring shields' advance, "International Journal of Mining Science and Technology" 2015, 3, 25: 361-367.
[9] Płonka M., Rajwa S., Lubosik Z.: Ocena pracy obudowy zmechanizowanej na podstawie danych $z$ monitoringu ciśnień i postępu sekcji, "Przegląd Górniczy" 2017, 73, 4: 25-33.

[10] Trueman R., Hutchinson I.: The use of shield monitoring data for predicting in advance roof control problems on longwall faces, "Mining Technology" 2018, 127, 4: 209-218.

[11] Trueman R., Lyman G., Cocker A.: Longwall roof control through a fundamental understanding of shield-strata interaction, "International Journal of Rock Mechanics \& Mining Sciences" 2009, 46, 2: 371-380.

[12] Medhurst T.P.: Practical considerations in longwall support behaviour and ground response, https://ro.uow.edu.au/coal/72/ [21.04.2021].

[13] PI System Architecture, Planning and Implementation Course Version 2021, Course materials, http://cdn.osisoft.com/ learningcontent/pdfsPISystemArchitecturePlanningAnd ImpleplementationWorkbook.pdf [26.04.2021].

TOMASZ CICHY, M.SC. ARTUR SEKTA, M.Sc. Jastrzębska Spótka Weglowa S.A. al. Jana Pawta II 4, 44-330 Jastrzębie-Zdrój, Poland $\{t c i c h y, a s e k t a\} @ j s w . p l$

(C) 2019 Authors. This is an open access publication, which can be used, distributed and reproduced in any medium according to the Creative Commons CC-BY 4.0 License. 


\title{
Monitorowanie ciśnienia w stojakach obudowy zmechanizowanej w wybranych ścianach w Jastrzębskiej Spółce Węglowej S.A.
}

\begin{abstract}
Artykut przedstawia rolę systemów monitorowania podporności sekcji obudowy zmechanizowanej, wchodzacej $w$ skład kompleksów wydobywczych. Zaprezentowano systemy jej monitorowania podczas eksploatacji złoża węgla oraz sposób przesyłania pomiarów ciśnień $w$ stojakach hydraulicznych do systemu analitycznego wykorzystywanego w Jastrzębskiej Spótce Węglowej S.A. Przedstawiono wyniki oceny wspótpracy obudowy zmechanizowanej z górotworem oraz sposób ich prezentacji.
\end{abstract}

Słowa kluczowe: górnictwo, obudowa zmechanizowana, podporność

\section{WSTĘP}

W skład Jastrzębskiej Spółki Węglowej S.A. (JSW S.A.) wchodzi pięć kopalń węgla kamiennego, w których eksploatację pokładów węgla prowadzi się za pomocą nowoczesnych kompleksów wydobywczych. Obudowa zmechanizowana jest jednym $\mathrm{z}$ podstawowych elementów tych kompleksów, decydującym o bezpieczeństwie pracowników i stateczności wyrobiska ścianowego i tym samym zapewniającym odpowiedni poziom wydobycia [1]. Istota działania obudowy zmechanizowanej sprowadza się do kontrolowanego obniżania obudowy, w przypadku gdy jest ona obciążana ze strony stropu siłą wynikającą z podporności roboczej samej obudowy. Podporność robocza to parametr określający graniczną zdolność obudowy zmechanizowanej do przenoszenia nacisków pochodzących od stropu otwartego eksploatacją górniczą. Mierzona jest ona jako nacisk skał stropowych na pojedynczą sekcję obudowy, wywołujący w stojakach hydraulicznych ciśnienie równe nastawie na blokach zaworowych chroniących te stojaki $[2,3]$. Oczywiste jest więc, że właśnie kontrola tego ciśnienia jest bardzo istotna w procesie eksploatacji pokładu węgla. Opisane systemy pomagają w prowadzeniu sekcji, umożliwiają wizualizację takich parametrów jak ciśnienie w stojakach hydraulicznych sekcji, czas wykonywania pomiarów, czas przebiegu operacji technologicznych, momentów wystąpienia nieprawidłowości czy awarii. Aktualnie w JSW S.A. systemy monitoringu pracują na kilku ścianach, a docelowo mają być zastosowane na wszystkich. Pamiętajmy, że są one kosztowne i z tego względu w pierwszej kolejności wyposaża się obudowy zmechanizowane pracujące w najtrudniejszych warunkach geologicznych [4].

\section{ANALIZA DANYCH}

W JSW S.A. od kilku lat funkcjonuje Centrum Zaawansowanej Analityki Danych, którego zadaniem jest m.in. analizowanie danych $\mathrm{z}$ procesów technologicznych $\mathrm{z}$ wykorzystaniem zintegrowanego systemu informatycznego do zarządzania danymi pochodzacymi z procesów produkcji, w skład którego wchodzi centralny serwer danych technologicznych (CSDT). System opiera się na platformie umożliwiającej przetwarzanie dużych zbiorów informacji w czasie rzeczywistym, pozwalającej na łatwą integrację z systemami biznesowymi i zapewniającej równocześnie bezpieczeństwo teleinformatyczne systemów technicznych. Dane ze wszystkich kompleksów ścianowych objętych systemami monitorowania sekcji obudowy zmechanizowanej są przesyłane do CSDT i przetwarzane w celu uzyskania szerokiej oceny współpracy obudowy zmechanizowanej z górotworem. Informacje te są określane na podstawie ciśnienia panującego w stojakach sekcji obudowy zmechanizowanej. Uzyskane wyniki są przedstawiane i raportowane odpowiednim służbom kopalni.

\section{EKSPLOATACJA ZŁOŻA}

Do eksploatacji podziemnych złóż węgla systemem ścianowym stosuje się zmechanizowany kompleks wydobywczy, w skład którego wchodzi m.in. obudowa zmechanizowana. Jej głównym zadaniem jest zapewnienie stateczności wyrobiska ścianowego, jak również bezpieczeństwa załogi. Jednym z kluczowych działań poprawiających bezpieczeństwo pracy oraz pozwalających na zwiększenie efektywności produkcyjnej jest ocena pracy przedmiotowej obudowy 
zmechanizowanej. Analizując współpracę obudowy zmechanizowanej z górotworem, możemy określić pewne aspekty mające istotny wpływ na stateczność wyrobiska ścianowego. Utrata stateczności wyrobiska powoduje powstanie obwału lub zawału stropu w ścianie, co może być związane $\mathrm{z}$ następującymi nieprawidłowościami w pracy obudów zmechanizowanych, tj. nieprawidłowym doborem sekcji do określonych warunków geologiczno-górniczych, awariami (uszkodzeniem) poszczególnych elementów sekcji, niewłaściwą obsługą (użytkowa-

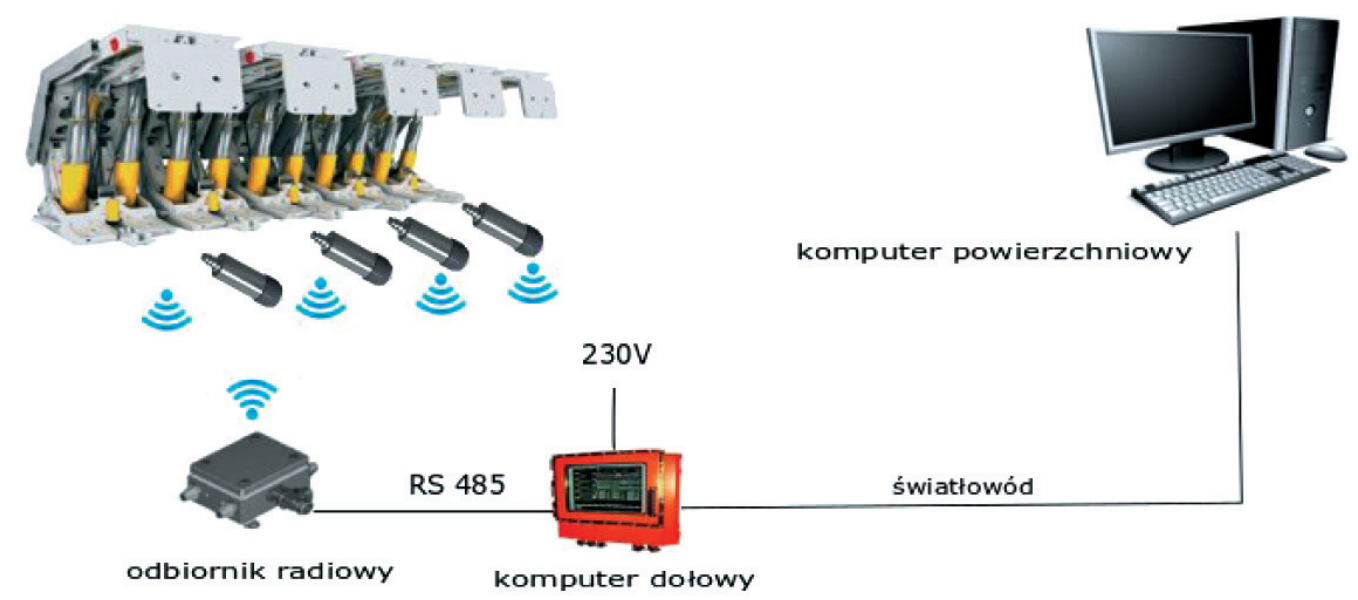

Rys. 1. System monitoringu podporności obudowy zmechanizowanej niem) sekcji i nieprawidłową postacią geometryczną konstrukcji sekcji [5, 6]. Dzięki monitoringowi cyklu pracy sekcji [7, 8] możemy pozyskać m.in. informacje zarówno na temat uszkodzeń w układzie podpornościowym sekcji lub niewłaściwej wartości podporności wstępnej [9], jak i dotyczące zawisania skał za sekcjami obudów zmechanizowanych powodujących znaczny wzrost obciążenia sekcji ze strony górotworu [10-12]. Widok sekcji wraz ze schematem systemu transmisji danych przedstawia rysunek 1 .

\section{SYSTEMY POMIAROWE}

W celu zapewnienia prawidłowych warunków utrzymania stropu oraz pracy sekcji obudowy zmechanizowanej wyposaża się je w odpowiednie systemy pomiarowe i sygnalizacyjne. Obecnie dokonuje się pomiarów i rejestracji ciśnień z podtłokowych części stojaków głównych sekcji obudów zmechanizowanych. Informacje te z monitorowanych ścian w kopal- niach JSW S.A. spływają do Centrum Zaawansowanej Analityki Danych.

Systemy pomiarowe pozwalają na lokalne monitorowanie pracy obudowy za pomocą komputerów przystosowanych do pracy w warunkach dołowych, jak również na powierzchni kopalni. Na rysunkach 2 i 3 przedstawiono okna monitoringu sekcji obudów zmechanizowanych z wykorzystaniem systemów Centrum Hydrauliki DOH sp. z o.o. oraz Grupy FAMUR S.A.

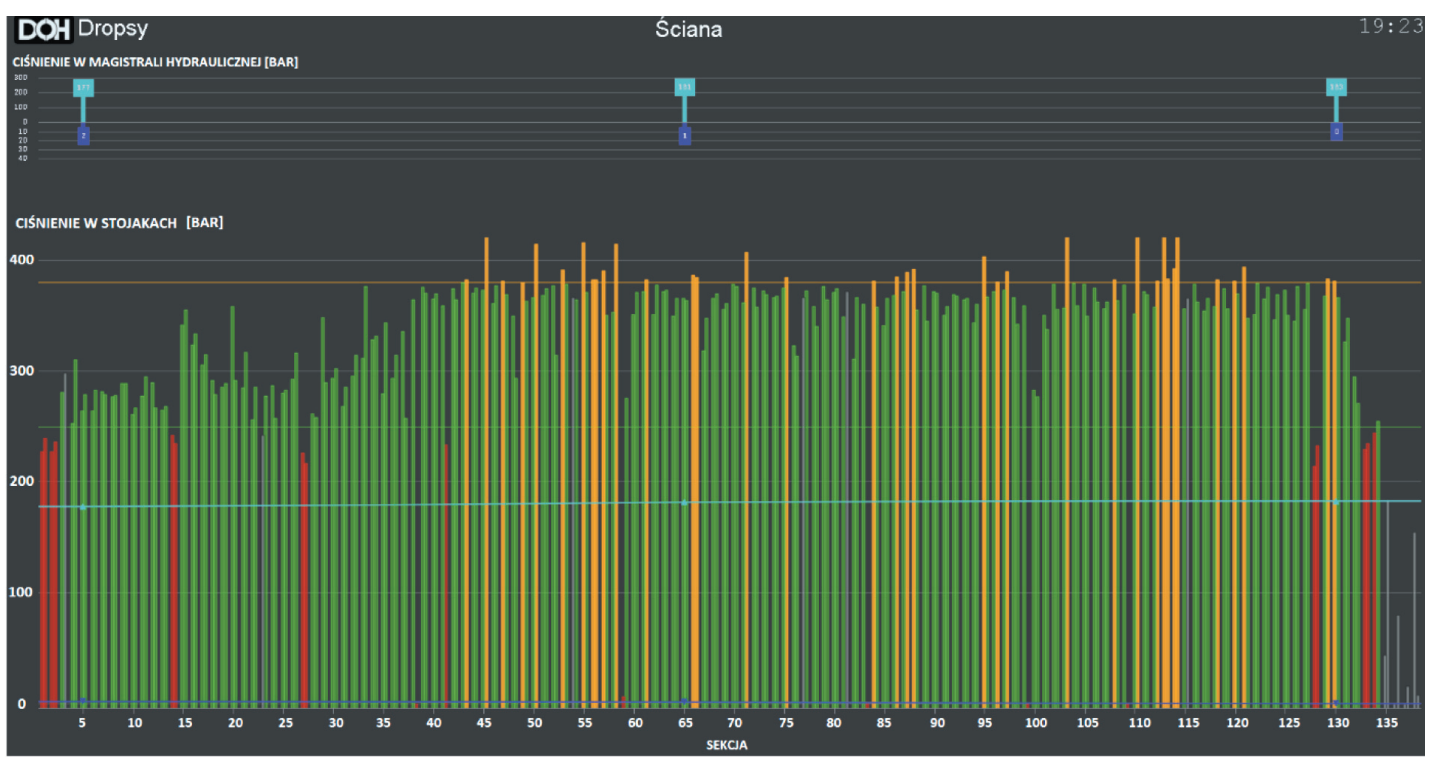

Rys. 2. Rozkład ciśnień w stojakach obudowy zmechanizowanej - system Centrum Hydrauliki DOH sp. z o.o. 


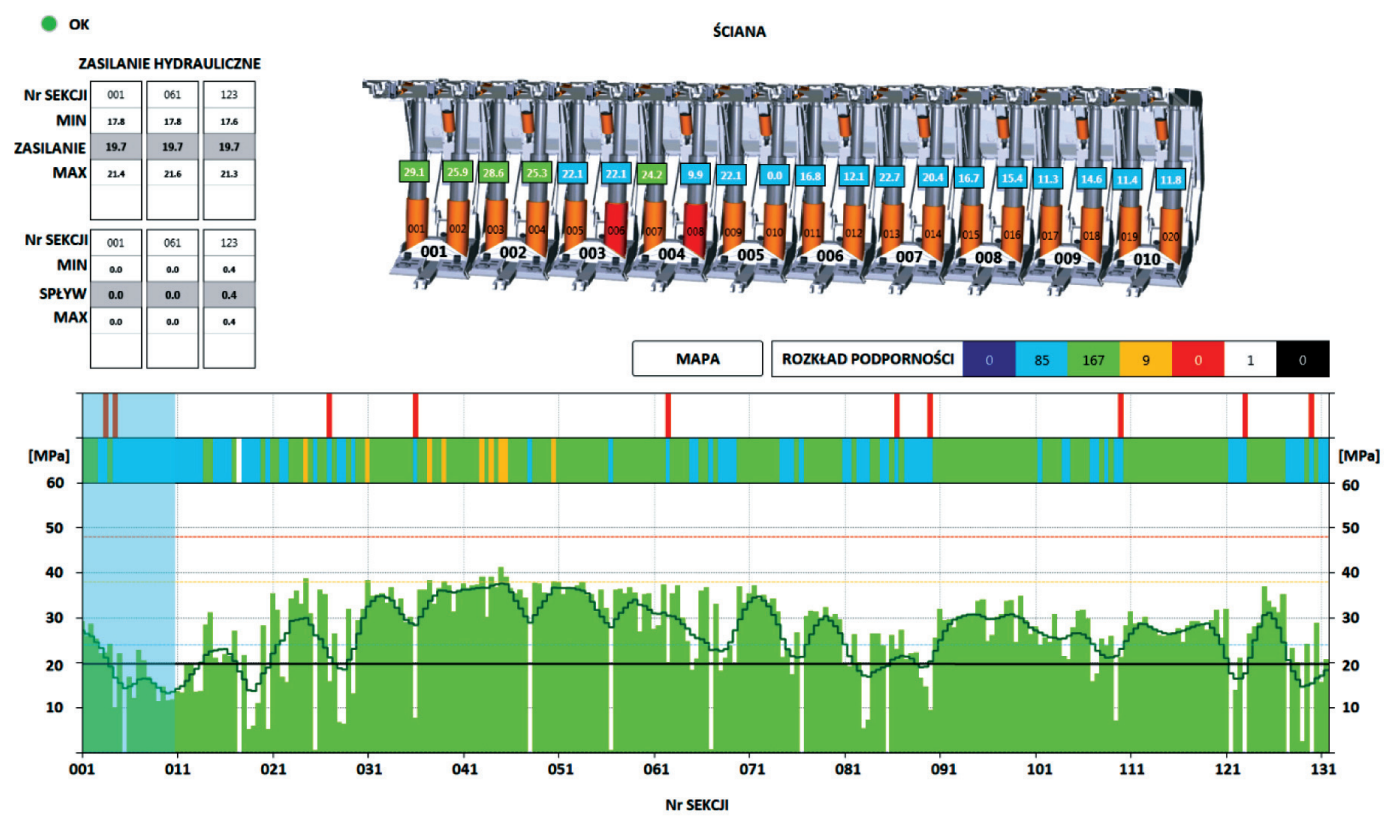

Rys. 3. Rozkład ciśnień w stojakach obudowy zmechanizowanej - system Grupy Famur

\section{ANALIZY I ALERTY}

W wyniku przeprowadzanych analiz ciśnienia w podtłokowych przestrzeniach stojaków w trybie rzeczywistym identyfikowany jest szereg zdarzeń, na które należy odpowiednio reagować. Na rysunku 4 jest widoczna asymetria ciśnień pomiędzy stojakami sekcji, która wskazuje na nieszczelność w układzie hydraulicznym stojaka. Widoczne to jest po porównaniu z prawidłowym cyklem obudowy zmechanizowanej (rys. 5). Rysunek 6 przedstawia zadziałanie zaworu upustowego, który powinien zadziałać przy określonej nastawie ciśnienia. Nie pozwala on na wzrost ciśnienia powyżej dopuszczalnej wartości określonej przez producenta sekcji. Istotnymi parametrami również identyfikowanymi na podstawie ciśnień są rabowanie i rozparcie sekcji oraz ciśnienie w magistrali zasilającej [4].

Istotne jest, aby wyniki analiz były dostarczane w czasie rzeczywistym i trafiały bezpośrednio do osób odpowiedzialnych za prawidłową pracę kompleksu wydobywczego - służby utrzymania ruchu w kopalni. Nie jest to proste ze względu na dużą skalę produkcyjną JSW S.A. Zadanie to zostało wykonane za pomocą narzędzi firmy OSISoft - PI System [13]. Podstawowe informacje $\mathrm{z}$ danego kompleksu ścianowego oraz z pojedynczej sekcji przedstawione są kolejno na rysunkach 7 i 8 . Osoba korzystająca $z$ tych informacji powinna bardzo szybko ocenić pracę sekcji obudowy zmechanizowanej w zakresie jej współpracy z górotworem. Zbiorcze zestawienie wszystkich alertów i istotnych zdarzeń zachodzących podczas pracy obudowy zmechanizowanej (tzw. mapa zdarzeń) zostało przedstawione na rysunku 9. Widoczne są tam zdarzenia występujące na poszczególnych stojakach obudowy zmechanizowanej za ostatnią dobę, takie jak cykle pracy, asymetria podparcia, wielokrotne zadziałanie zaworu upustowego, niewłaściwa wartość podporności wstępnej.

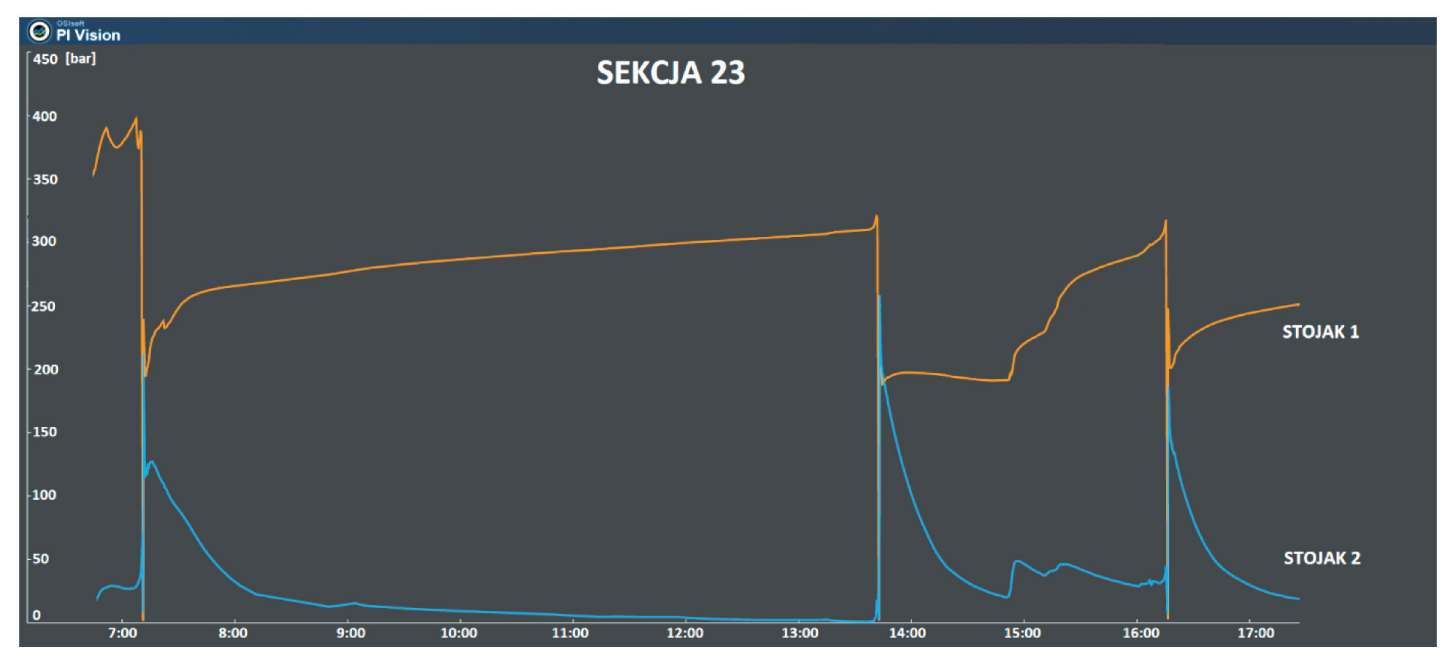

Rys. 4. Asymetria ciśnienia pomiędzy stojakami sekcji 


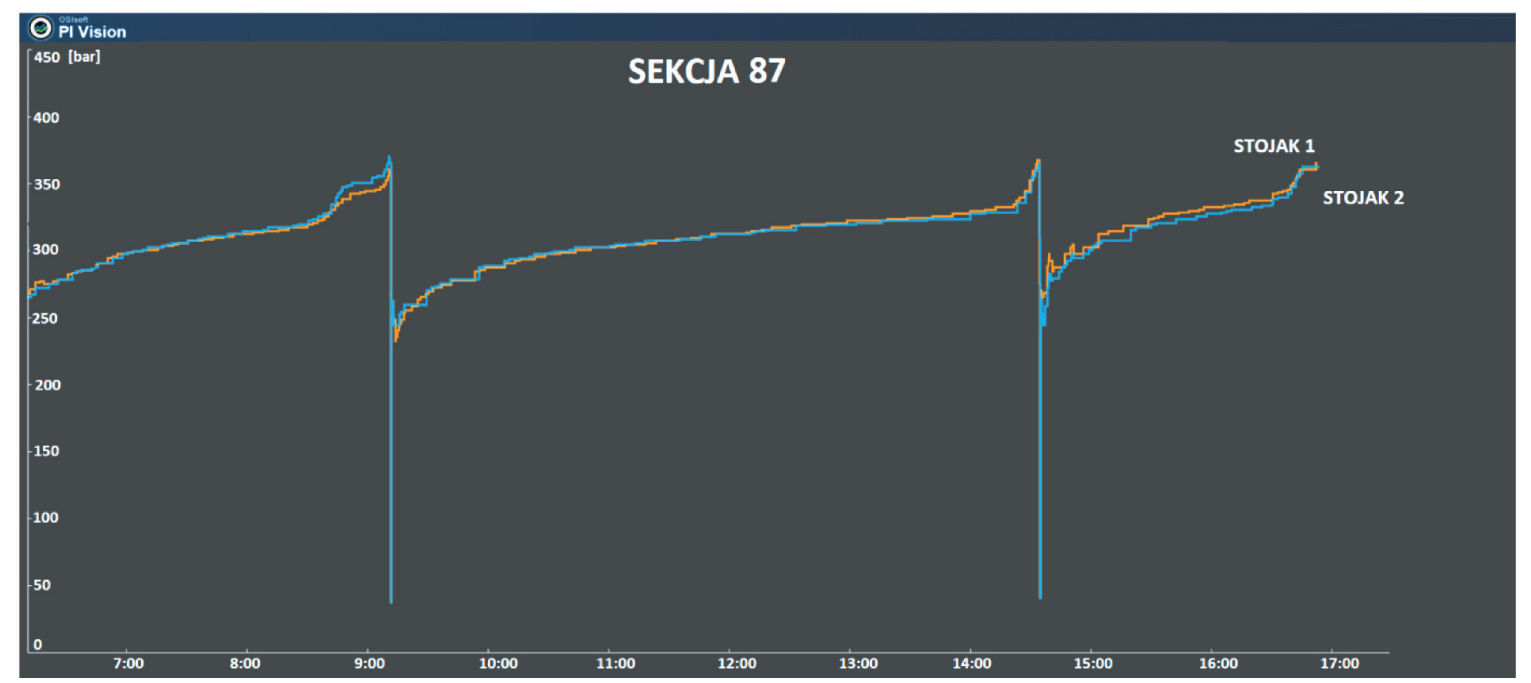

Rys. 5. Pomiar ciśnienia podczas kolejnych cykli pracy sekcji

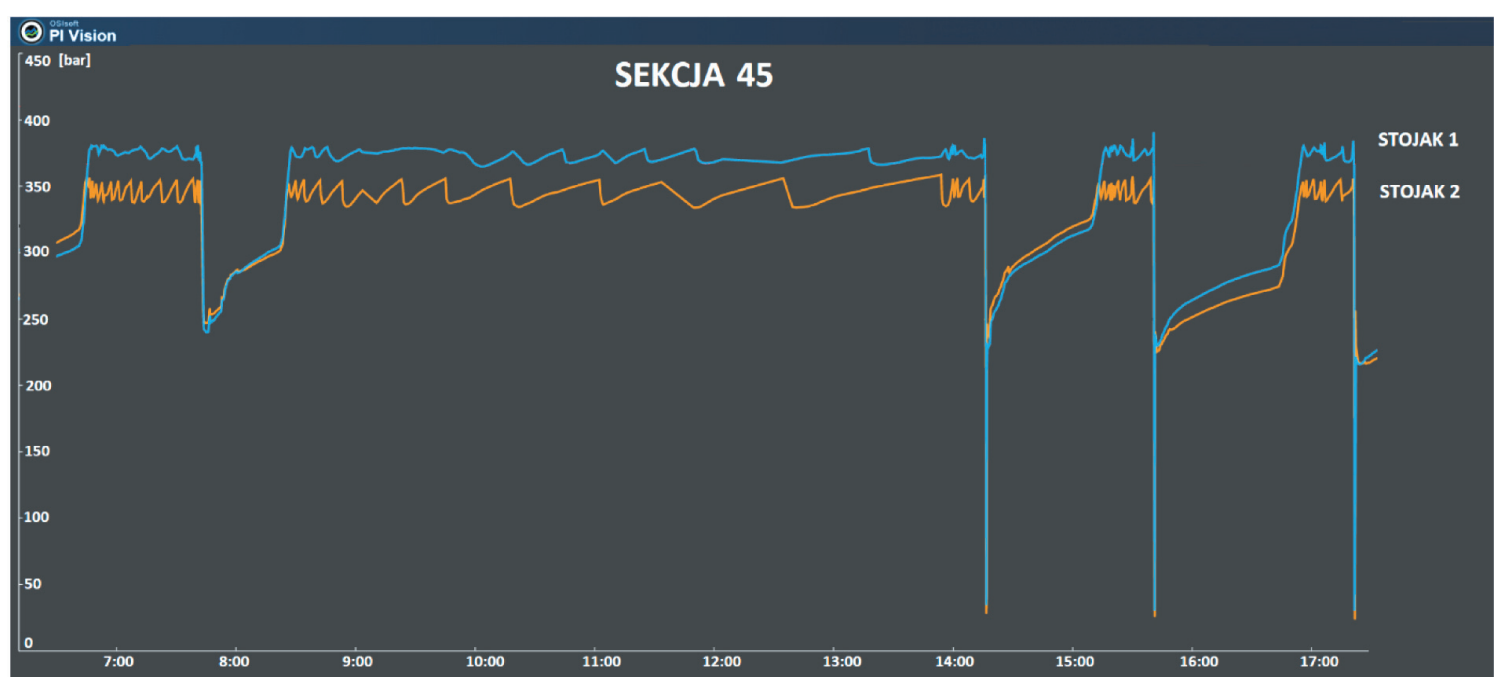

Rys. 6. Zadziatanie zaworu upustowego w stojakach sekcji

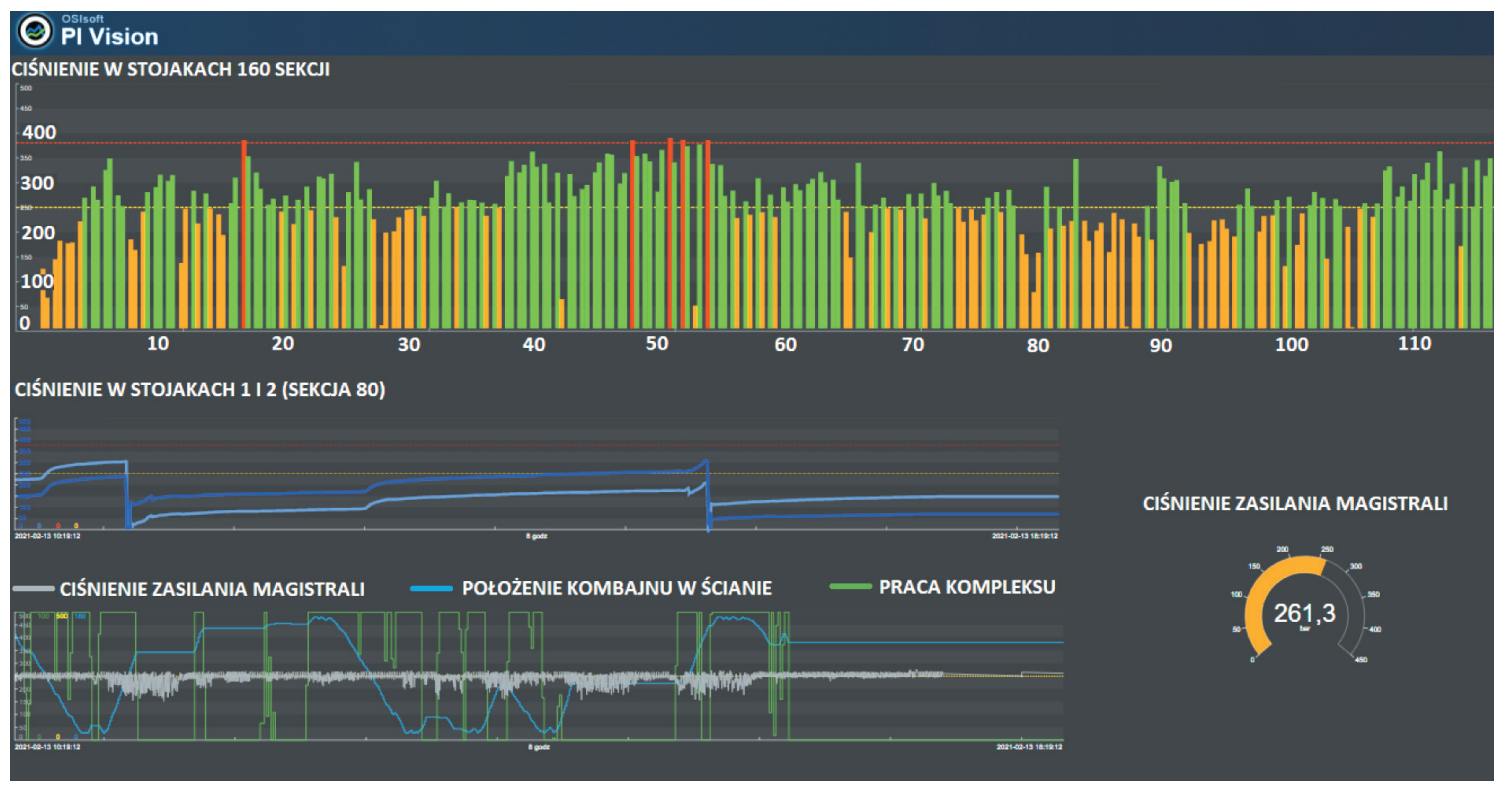

Rys. 7. Widok bieżacy ciśnień w sekcjach obudowy zmechanizowanej 


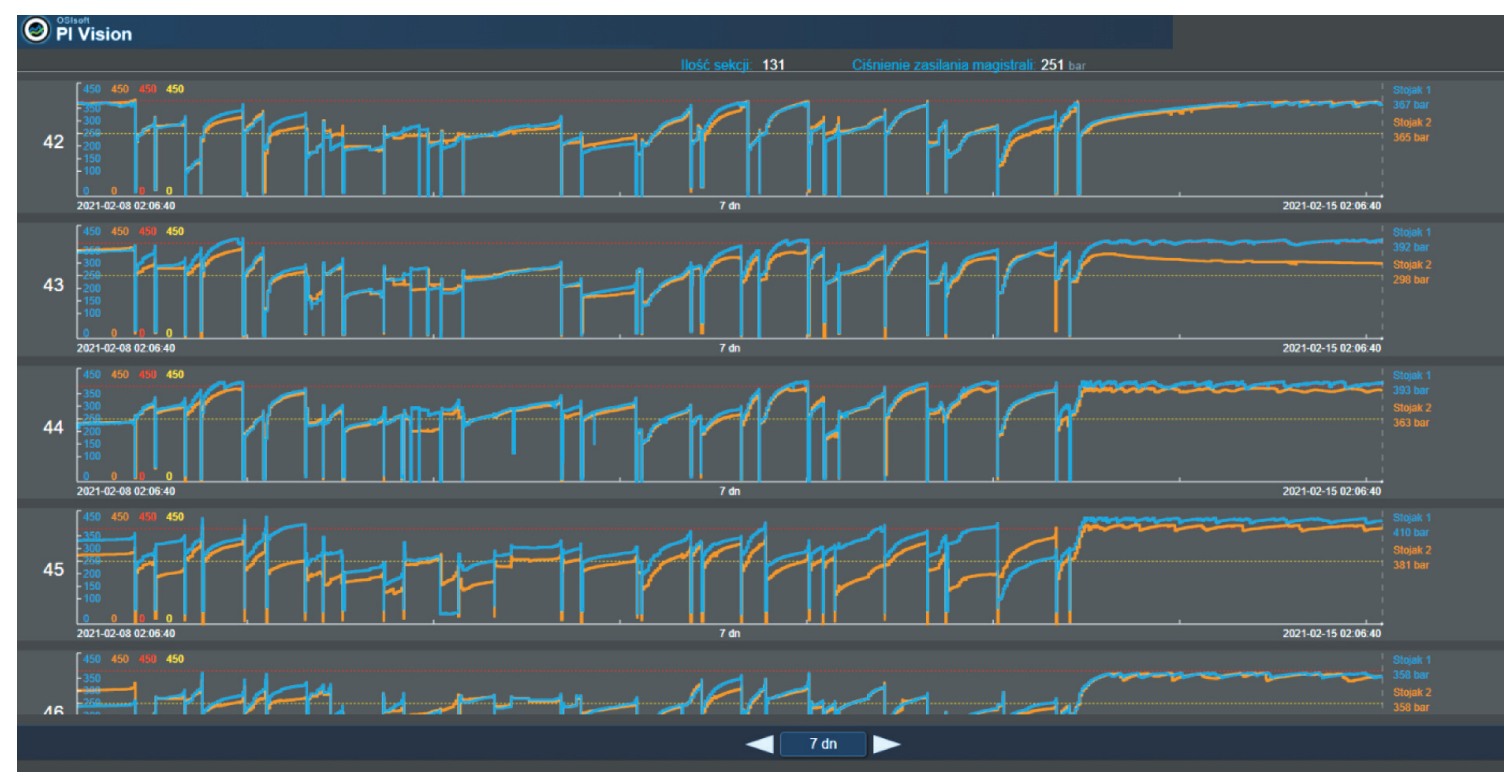

Rys. 8. Widok ciśnienia w wybranych sekcjach

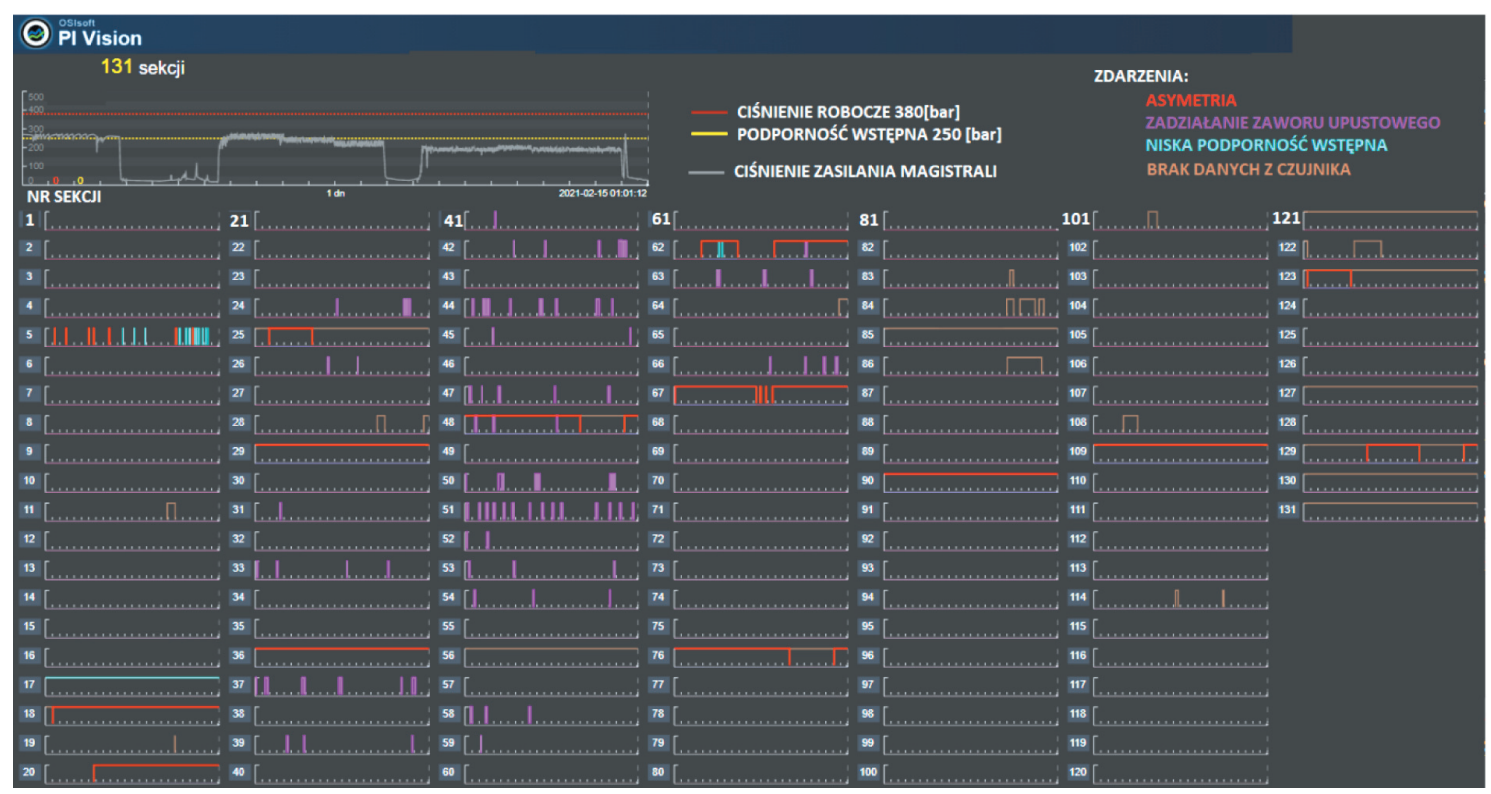

Rys. 9. Sygnalizacja wystapienia zdarzeń w sekcjach obudowy zmechanizowanej

\section{PODSUMOWANIE}

Wdrożone systemy monitoringu i analiz podporności sekcji pozwalają na szeroką ocenę pracy obudowy zmechanizowanej w kontekście współpracy z górotworem. Ze względu na różnorodność czynników mających wpływ na prowadzenie obudowy dokonano oceny współpracy, analizując czynniki geologiczne i organizacyjne. Ciągła kontrola podporności pozwala na ocenę naprężenia górotworu oraz na szybszą reakcję pracowników w celu osiągnięcia poprawnego stanu równowagi górotworu, który został zakłócony podczas wybierania węgla. Działania te pozwalają skuteczniej niwelować wpływ odspojenia i poluźnienia górotworu (obwały stropu) na przebieg wydobycia. Istotnym czynnikiem podczas prowadzenia obudowy jest organizacja pracy. Dzięki monitoringowi cyklu pracy sekcji pozyskujemy m.in. informacje na temat uszkodzeń w układzie podpornościowym sekcji lub niewłaściwej wartości podporności wstępnej, a także zbyt długiego opóźnienia w podparciu świeżo odsłoniętego stropu. Wpływa to na poprawę kultury pracy załogi w ścianie.

Uzyskane w ten sposób korzyści w istotny sposób poprawiają bezpieczeństwo załogi i efektywność produkcyjną oraz zwiększają żywotność obudowy zmechanizowanej. 


\section{Literatura}

[1] Rajwa S., Prusek S., Walentek A., Płonka M.: Wpływ wybranych czynników na wspótpracę obudowy zmechanizowanej z górotworem $i$ warunki prowadzenia ściany, „Wiadomości Górnicze" 2015, 66, 10: 533-543.

[2] Obudowa zmechanizowana Hydrotech-JZR-14/39-PO - instrukcja obstugi $i$ konserwacji Nr:01/2019/IOK, Jastrzębskie Zakłady Remontowe Spółka z o.o. [praca niepublikowana].

[3] Kulakiewicz A., Marianowski J.: Nowe rozwiazanie zabezpieczeń funkcjonowania upodatnionej obudowy zmechanizowa$n e j$, „Napędy i Sterowanie” 2011, 13, 7/8: 152-155.

[4] Płonka M.: Obraz podporności sekcji obudowy zmechanizowanej usytuowanej na pozycjach skrajnych na podstawie danych z systemów monitoringu, „Przeglad Górniczy” 2018, 74, 3: 34-40.

[5] Rajwa S.: Główne przyczyny utraty stateczności wyrobiska ścianowego, „Bezpieczeństwo Pracy i Ochrona Środowiska w Górnictwie” 2017, 3: 3-12.

[6] Rajwa S.: Rozdział 4. Stateczność wyrobiska ścianowego, [w:] $\mathrm{K}$. Stoiński (red.), Zmechanizowane obudowy ścianowe dla warunków zagrożenia wstrzasami górotworu, Główny Instytut Górnictwa, Katowice 2018: 73-88.

[7] Peng S.S.: Longwall mining, wyd. 2, Department of Mining Engineering, West Virginia University, Morgantown 2006.

[8] Cheng J., Wan Z., Peng S.S., Liu S., Ji Y.: What can the changes in shield resistance tell us during the period of shearer's cutting and neighboring shields' advance, ,International Journal of Mining Science and Technology" 2015, 3, 25: 361-367.
[9] Płonka M., Rajwa S., Lubosik Z.: Ocena pracy obudowy zmechanizowanej na podstawie danych z monitoringu ciśnień i postępu sekcji, „Przegląd Górniczy” 2017, 73, 4: 25-33.

[10] Trueman R., Hutchinson I.: The use of shield monitoring data for predicting in advance roof control problems on longwall faces, „Mining Technology” 2018, 127, 4: 209-218.

[11] Trueman R., Lyman G., Cocker A.: Longwall roof control through a fundamental understanding of shield-strata interaction, „International Journal of Rock Mechanics \& Mining Sciences" 2009, 46, 2: 371-380.

[12] Medhurst T.P.: Practical considerations in longwall support behaviour and ground response, https://ro.uow.edu.au/coal/72/ [21.04.2021].

[13] PI System Architecture, Planning and Implementation Course Version 2021, Materiał szkoleniowy, http://cdn.osisoft.com/ learningcontent/pdfs/PISystemArchitecturePlanningAnd ImplementationWorkbook.pdf [26.04.2021].

mgr inż. TOMASZ CICHY

mgr inż. ARTUR SEKTA

Jastrzębska Spółka Węglowa S.A.

al. Jana Pawta II 4

44-330 Jastrzębie-Zdrój

\{tcichy,asekta\}@jsw.pl

(C) 2019 Autorzy. Jest to publikacja ogólnodostępna, którą można wykorzystywać, rozpowszechniać i kopiować w dowolnej formie zgodnie z licencja Creative Commons CC-BY 4.0. 